\title{
Tahap Pengembangan Smart Kampung di Desa Ketapang Kabupaten Banyuwangi
}

\author{
"Vincentius Paulinus Baru, Achmad Djunaedi, Yori Herwangi \\ ${ }^{*}$ 1Departemen Teknik Arsitektur dan Perencanaan Magister Perencanaan Wilayah dan Kota Universitas Gajah Mada \\ Email: barupaul459@gmail.com
}

\section{INFO ARTIKEL}

\section{Riwayat Artikel:}

Diterima : 30-07-19

Disetujui : 02-10-19

\section{Kata Kunci:}

Smart city

Smart kampung

Tahapan

pengembangan

Faktor-faktor yang

berpengaruh

\begin{abstract}
ABSTRAK
Abstrak:Smart village merupakan sebuah konsep yang baru berkembang di dunia dan menjadi fenomena baru digunakan untuk menyelesaikan berbagai permasalahan di desa. Desa Ketapang merupakan salah satu desa di kabupaten Banyuwangi yang telah berhasil mengadopsi konsep ini untuk dikembangkan di wilayah mereka. Dalam penerapannya berhasil digunakan untuk mengatasi berbagai permasalahan yang terjadi di desa. Untuk itu perlu dilakukan penelitian untuk menjelasakan tahapan pengembangan dan faktor-faktor apa saja yang berpengaruh dalam pengembangan konsep ini sehingga berhasil. Penelitian ini menggunakan pendekatan kualitatif dengan metode studi kasus eksploratif berbekal sedikit teori dan mengeksplorasi kasus dilapangan. Hasil dari penelitian ini, tahapan perkembangan smart village terdiri dari empat tahap yaitu tahapan persiapan (2011-2015), tahapan pelaksanaan (Akhir 2015-2016), tahap pengembangan (2017-2018) dan tahap monitoring dan evaluasi. Program kegiatan yang dilakukan dalam tahap persiapan terdiri dari pembangunan infrastruktur TIK dan pengembangan aplikasi layanan, penyiapan sumber daya aparatur pemerintah dan pengembangan komunitas masyarakat.Faktor-faktor yang berpengaruh dalam tahapan pengembangan smart kampung antara lain faktor kepemimpinan, teknologi, dukungan warga dan alokasi anggaran.
\end{abstract}

Abstract:Abstract: Smart village is a concept that has just developed in the world and has become a new phenomenon used to solve various problems in the village. Ketapang Village is one of the villages in Banyuwangi district that has successfully adopted this concept to be developed in their area. In its implementation, it was successfully used to overcome various problems that occurred in the village. For this reason, research is needed to explain the stages of development and what factors are influential in developing this concept so that it works. This study uses a qualitative approach with explorative case study methods armed with little theory and explores cases in the field. The results of this study, the stages of development of smart village consist of four stages, namely the preparation stage (2011-2015), the implementation stage (End of 2015-2016), the development stage (2017-2018) and the monitoring and evaluation stages. Factors that influence the stages of smart village development include leadership, technology, citizen support, and budget allocations. The phases of the village smart development of Ketapang consist of the preparation stage (20112015), the stage of implementation (2015-2016), the development stage (2017-2018), and the Monitoring and evaluation stage (in each year). The Program activities conducted in the preparatory phase consist of ICT infrastructure development and Service application development, government apparatus resource preparation and community development. 


\section{A. LATAR BELAKANG}

Dalam beberapa dekade terahir, di dunia terutama di negara-negara berkembang seperti Indonesia laju pertumbuhanpenduduk perkotaan berkembang cepat akibat urbanisasi. Berdasarkan data UNFA PBB diperkirakan tahun 2050 mendatang dua pertiga populasi global bermigrasi ke kota[1].Migrasi penduduk cepat ke kota akibat ketertingalan pembangunan di desa.Urbanisasi menyebabkan banyak permasalahan yang terjadi, baik di wilayah perkotaan maupun pedesaan. Permasalahan yang terjadi seperti kemacetan, polusi udara, kemiskinan, kekumuhan, berkurangnya lahan produksi pertanian, budaya masyarakat yang semakin merosot, tingkat kemiskinan yang tinggi, kualitas hidup masyakat rendah dan berbagai permasalahan lainnya yang terus terjadi.

Untuk mengatasi berbagai masalah yang terjadi baik di kota maupun di desa dibutuhkan kebijakan dan solusi yang cerdas (smart solution)dari pemerintah. Salah satu solusi cerdas yang dikembangkan dengan memanfaatkan perkembangan Teknologi Informasi dan Komunikasi (TIK) adalah dengan pengembangkan konsep smart city. Smart citymerupakan sebuah kota yang mampu menggunakan Sumber Daya Manusia (SDM), Modal Sosial, dan Infrastruktur Teknologi Modern (Information and Communication Technology) untuk mewujudkan pertumbuhan ekonomi berkelanjutan dan meningkatkan kualitas hidup warga yang tinggi dengan manajemen pengelolaan sumber daya alam yang bijaksana melalui pemerintahan berbasis partisipasi masyarakat[2].Konsep ini menekankan pada penggunaan teknologi nformasi dan komunikasi untuk mengatasi berbagai permasalah yang terjadi dengan lebih efektif dan efisien.

Menurut Deaklin dan Allwinkle (2007)[3] perkembangan konsepsmart city mulai berkembang sejak tahun 1990-an, saat internet mulai berkembang pesat di dunia. Pada periode ini, perkembanganya masih terbatas pada pelayanan satu arah dengan kebijakan statis dan terbatas. Perkembangan pada fase kedua tahun 2000-an, dimana TIK yang mulai berkembang cepat menyebabkan komunikasi dapat dilakukan dua arah secara realtime dari lokasi yang berbeda. Perkembangan pada fase ketiga tahun 2004/2005, lebih pada konsep intelcities yaitu pengembangan sistem terintegrasi pada seluruh layanan perkotaan secara online berbasis website pemerintah. Perkembangan pada fase empat setelah tahun 2005 dimana konsep smart city berkembang cukup pesat. Pada saat ini dengan konsep smart citypengembangannya di berbagai level program.Program-program yang dikembangkan dalam berbagai aplikasi layananuntuk memudahkan warga ikut berpartisipasi dalam forum-forum kebijakan publik berbasis online.Berbagai inovasi tersebut bertujuan untuk meningkatkan kualitas hidup warga kotanya.

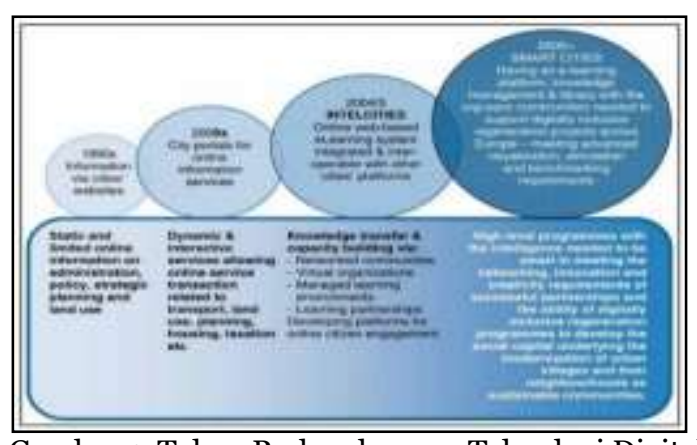

Gambar 1. Tahap Perkembangan Teknologi Digital Sumber : Deaklin dan Allwinkle (2007)

Dari penjelasan perkembangan konsep smart city dalam perkembangan kota diatas menurut Deaklin dan Allwinkle (2007) faktor perkembangan teknologi berperan penting dalam pengembangan konsep smart city. Namun menurut Nam dan Pardo's selain faktor teknologi kedua faktor yang penting yang berpengaruh dalam pengembangan konsep smart city adalah faktor manusia dan faktor institusi[4]. Ketiga faktor tersebut tidak bisa berdiri sendiri, namun selalu terintegrasi antara faktor teknologi, faktor institusi dan faktor manusia menjadi dasar dalam pengembangan konsep smart city saat ini. Dalam pengembangan kosep smart city mencakup semua aspek layanan kota. Menurut Giffinger at al., (2007) membagi dimensi smart city menjadi 6 dimensi yaitu Smart Enonomy, Smart Governance, Smart Environment, Smart People, Smart Mobility, Smart Living[5]. Smart Economy (ekonomi cerdas) bertujuan untuk meningkatkan peluang dan daya saing, produktifitas dan jaringan pasar baik lokal maupun internasional. Smart Governance (tata kelola pemerintahan yang cerdas) bertujuan untuk terciptanya manajemen birokrasi efektif dan efisien dan berjalannya fungsi pemerintahan daerah sebagai lembaga pelayanan publik yang efektif, transparan dan bertanggung jawab dengan bantuan Teknologi Informasi dan Komunikasi (TIK). Smart Envirionment (lingkungan cerdas) bertujuan untuk mengatur penggunaan sumber dayasecara berkelanjutan dan berhubungan dengan pengelolaan manajemen polusi. Smart People (masyarakat cerdas)bertujuan pengembangan modal manusia dan modal sosial untuk mewujutkan manusiamanusia yang kreatif dan berpartisipasi dalam kehidupan publik. Smart Mobility (mobilitas cerdas) bertujuan untuk mengintegrasikan sistem transportasi yang memanfaatkan ITC untuk mempermudah mobilitas barang dan jasa ataupun pergerakan warga kotanya. Smart Living (hidup yang cerdas)bertujuan untuk untuk meningkatkan kualitas hidup warga kota. Aspek ini terdiri dari beragam aspek kualitas hidup mulai dari budaya, kesehatan, keamanan, perumahan, pariwisata dan lain-lainya. 


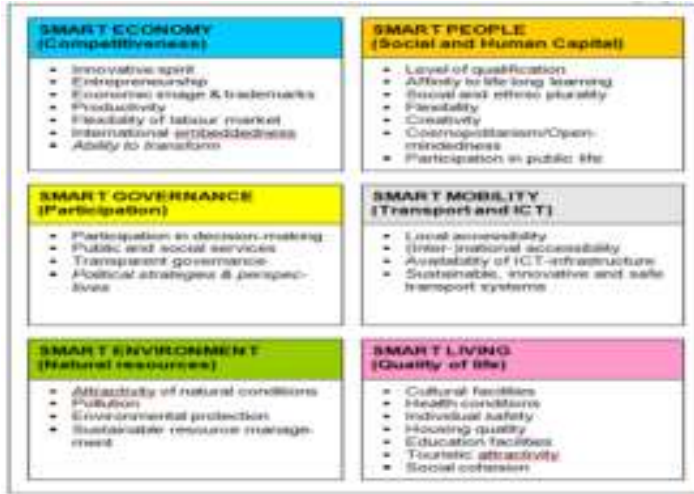

Gambar 2. Dimensi Smart City

Sumber : Giffinger et.al., (2007)

Pengembangankonsep smart citydalam beberapa waktu belakangan ini menjadi fenomena baru dalam pengelolaan kota, karena dinilaiberhasil dalam mengatasi berbagai permasalah yang terjadi di berbagai kota-kota di dunia. Karena berhasil pemanfaatanya, sehingga konsep ini diadopsi untuk dikembangkan di berbagai desa di dunia dengan nama smart village. Menurut Wiswanadham (2010) smart villageadalah sebuah konsep layanan yang dikelola oleh masyarakat yang hidup di wilayah pedesaan memanfaatkan teknologi informasi untuk melakukan berbagai aktifitas desa secara efisein dan efektif[5], sedangkan menurut Chatterjee \& Kar (2011) smart village adalah sebuh desa yang menyediakan kumpulan layanan kepada masyarakat atau penduduknya yang ramah terhadap bisnis warga dan bertindak sebagai penyedia bagi para pelaku ekonomi di desa dan menyediakan semua layanan yang diperlukan warga desa dengan cara yang lebih efektif dan efisien dengan bantuan TIK[6]. Konsep smart city ataupun konsep smart villagepada dasarnya menekankan penggunaan teknologi informasi dan komunikasi (TIK) sebagai basis dasar untuk mengelola dan membangun kota atau desa secara lebih efektif dan efisien sehingga berdampak pada peningkatkan kualitas hidup masyarakat.

Pada tahun 2015, konsep ini diadopsi oleh pemerintah kabupaten Banyuwangi untuk dikembangkan di wilayahnya sebagai salah kebijakan strategis untuk mengatasi permasalahan yang terjadi di wilayah ini. Konsep yang dikembangkan di Banyuwangi dibrending dengan sebutan "Smart Kampung". Smartkampung adalahkonsep pengembangan masyarakat dalam suatu komunitas untuk melakukan sesuatu secara cerdas/pintar/bijak dalam mengatasi berbagai permasalahan dengan kemampuan sumber daya yang tersedia dengan efisien di suatu wilayah yang dihuni oleh masyarakat yang membentuk komunitas sendiri dengan tatanan kehidupan yang terkait dengan adat istiadat setempat dan norma-norma yang berlaku didalamnya[7].

Pengembangan konsep ini bertujuan untuk mengatasi jarak yang berjauhan antara desa dan kota Banyuwangi sebagai pusat pelayanan pemerintah, agar dapat mendekatkan pelayanan pemerintah yang baik kepada masyarakat di desa. Sejak dikembangkan konsep smart kampung, dinilai berhasil dalam mengatasi permasalahan yang terjadi di kabupaten Banyuwangi sehinggapemerintah kabupaten Banyuwangi meraih penghargaan TOP IT dan Telco pada tahun 2017 dari Kementrian Komunikasi dan Informatika[8]. Smart kampung atau smart villagemerupakan konsep pembangunan desa yang baru berkembang, dimana dalam pengembangannya di kabupaten Banyuwangi berhasil meraih pengahargaansehinggamenarik untuk diteliti.Penelitian tentangtahapan pengembangan smart kampungpenting dilakukan untuk mengetahui bagaimanacerita sukses pengembangan konsep ini oleh pemerintah kabupaten Banyuwangi sehingga menjadi bahan pelembelarajan (lesson learn) untuk dikembangkan di wilayah lain.

\section{B. METODE PENELITIAN}

Penelitian ini akan menggunakan pendekatan kualitatif dengan metode studi kasus tunggal holistik. Menurut Creswellstudi kasus adalah merupakan salah satu jenis penelitian kualitatif, dimana peneliti melakukan eksplorasi secara mendalam terhadap program, kejadian, proses, aktivitas, terhadap satu atau lebih orang [10]. Yin (2002) untuk tipe penelitian dengan pertanyaan "how" (bagaimana) dan "why" (mengapa) dan memiliki fenomena fokus kontemporer, dan peneliti hanya sedikit memiliki peluang untuk mengontrol fenomena yang akan diteliti, maka strategi yang cocok digunakan adalah studi kasus[11]. Penelitian studi kasus juga dapat menyelidiki fenomena dalam konteks kehidupan nyata dan memiliki batasan-batasan yang tidak tegas antar fenomena dan konteks dan bukti yang digunakan bisa bersifat multisumber.

Berdasarkan kategori yang dibuat Yin mengenai tipe penelitian studi kasus dibagai menjadi tiga yaitu studi kasus eksploratoris, eksplanatoris dan deskriptif. Tipe penelitian yang digunakan dalama penelitian ini adalah model ekploratoris yang berbekal sedikit teori dan mengeksplorasi fenomena kasus untuk menjawab pertanyaan bagaimana.Yin (2002) membagi kategori analisis studi kasus kedalam tiga bentuk yaitu penjodohan pola (pattern matching), analisa pembangunan penjelesan (explanation bulding), dan analisa deret waktu (time series). Untuk penelitian ini mengunakan analisa deret waktu untuk menjelaskan tahapan pengembangansmart kampung di Desa Ketapang Kabupaten Banyuwangi.

Lokasi Penelitian studi kasus terletak di Desa Ketapang Kecamatan Kalipuro Kabupaten Banyuwangi. Pemilihan lokasi ini karena pengembangan program smart kampung telah berkembang baik di desa ini dari pada desa-desa lainnyadengan berbagai inovasi program yang berhasil dikembangkan di desa.

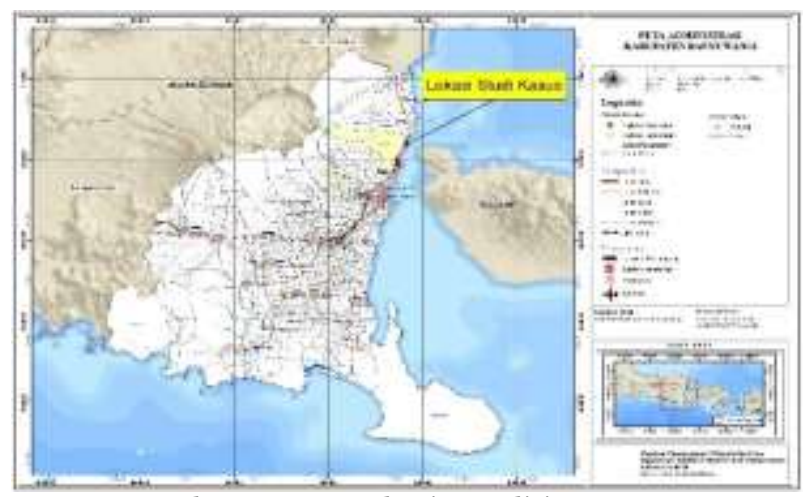

Gambar 3. Peta Lokasi Penelitian Desa Ketapang Kabupaten Banyuwangi Sumber. Analisis Penulis,2019 


\section{HASIL DAN PEMBAHASAN}

\section{Pelaksanaan Program Smart Kampung}

Jika dibandingkan dimensi smart city yang dikembangkan oleh Giffinger et.al (2007), makadalam pelaksanaanprogram smartkampung di Desa Ketapang ada beberapa dimensi yang telah dikembangkan antara lain:

\section{a. Smart Governance}

Smart governance merupakan penyelengaraan pemerintahan cerdas yang bertujuan untuk menciptakan manajemen birokrasi efektif dan efisien dan berjalannya fungsi pemerintahan daerah sebagai lembaga pelayanan publik yang efektif, transparan dan bertanggung jawab dengan bantuan teknologi informasi dan komunikasi (TIK). Beberapa program kegiatan yang telah dilaksananan terkait dengan pengelolaan pemerintahan cerdas di Desa Ketapang antara lain:

Sistem Informasi Manajemen Desa (SIMDes), merupakan portal yang digunakan untuk mengelola database kependudukan desa Ketapang secara online. Sistem ini terkoneksi dengan sistem database penduduk di tingkat kabupaten dalam aplikasi SIAK Online. Aplikasi digunakan utuk pengurusan surat keterangan administrasi penduduk maupun surat-surat keterangan lainnya seperti surat keterangan pernyataan miskin, surat keterangan pindah, dan lain-lain. Melalui sistem ini, pengurusan berbagai surat keterangan dapat dilakukan secara online di kantor desa dan memerlukan waktu yang cepat sekitar 3-5 menit sudah bisa cetak. Proses motong jarak dan waktu menjadi lebih pendek dan efisien bagi warga desa sehingga mereka mendapatkan pelayanan yang lebih berkualitas dari sebelumnya.

Portal Banyuwangi, merupakan portal layanan publik berbasis websiteyang berfungsi untuk pengurusan berbagai surat keterangan. Sistem ini dapat digunakan untuk mengurus 15 jenis surat keterangan seperti surat keterangan pindah, surat keterangan umum, surat keterangan lahir mati, surat keterangan kelahiran, surat keterangan dispensasi nikah, surat keterengan nikah, surat keterangan sumbangan atau bantuan, surat keterangan asal-usul, surat persetujuan mempelai, surat keterangan orang tua, surat keterangan wali hakim, surat keterangan wali nikah, surat keterangan izin keramainan.Dengan aplikasi ini penduduk desa dapat mengurus surat-surat keterangan secara langsung di kantor desa tanpa harus ke instansi yang bersangkutan di kota Banyuwangi. Semua proses dapat diselesaikan di kantor desa berlangsung cepat dan tapa pungutan biaya.

Procot Lahir Bawa Akta,merupakan sistem pelayanan publik berbasis website yang digunakan untuk pengurusan akta kalahiran dan kartu keluarga baru secara online. Melalui sistem ini, bayi yang baru lahir usia 1-3 hari bisa langsung diurus akta kelahiran di Puskesmas tempat dilahirkan sedangkan bayi yang berusia lebih dari 1 bulan proses pengurusan akta kelahiran dapatdilakukan di kantor desa. Sebelum ada programsmart kampung, semua proses pengurusan akta kelahiran harus dilakukan secara langsung di Kantor Dinas Kependudukan dan Catatan Sipil di Kota Banyuwangi, namun dengan program ini semua proses pengurusannya dapat dilakukan di kantor desadengan lebih mudah sehingga bisa membantu warga desa untuk mendapatkan pelayanan yang lebih baik.
Surat Pernyataan Miskin (SPM), merupakan sistem pelayanan berbasis website yang digunakan untuk pengurusan bantuan biaya pengobatan bagi keluarga miskin yang tidak mendapatkan BPJS kesehatan. Melalui program ini, keluarga miskin yang tidak memperoleh BPJS, mereka dapat menggurus SPM di kantor desa untuk mendapatkan bantuan biaya pengobatan di rumah akit pemerintah maupun swasta di Banyuwangi maupun rujukan pengobatan ke rumah sakit di Surabaya. Sebelum adanya program ini, untuk mendapatkan surat pernyataan miskin, warga desa harus mengurus surat-surat keterangan di beberapa instani yang berbeda. Proses tersebut memerlukan biaya, waktu dan tenaga yang banyak sehigga memberatkan warga desa, namun dengan program smart kampung saat ini semua proses tersebut dapat diselesaikan di desa.

$e$-village budgeting $(e-v b)$, merupakan sistem berbasis website yang digunakan untuk perencanaan dan pengelolaan keuangan secara online di desa. Aplikasi ini merupakan sebuah sistem perencanaan dan pelaporan keuangan desa berbasis online pertama di Indonesia. Sistem ini didesain untuk mengawal dana desa, sehingga pengunaan dana desa lebih transparan dan tepat sasaran. Dan juga dengan sistem ini dapat mencegah pendobolan perencanaan program pembangunan desa. Karena sistem ini sudah terintegrasi dengan sistem perencanaan pembanguan di tingkat kabupaten yang dikelola oleh BAPPEDA. Selain itu juga, dengan sistem ini partisipasi warga desa untuk ikut dalam proses perencanaan dan pengawasan pembangunan dapat berjalan dengan baik. Warga desa ikut merencanakan dan memastikan program-program pembangunan yang akan diangarkan dalam APBDes sesuai dengan kebutuhan warga desa. Melalui sistem ini perencanaan pembangunan desa lebih tepat sasaran dari sebelumnya.

E-village monitoring system (e-vms),merupakan sistem yang dibuat untuk mengawal kegiatan monitoring dan evaluasi (monev) keuangan desa berbasis online di desa. Aplikasi ini untuk mengontrol proses pembangunan fisik di desa. Melalui sistem ini, semua program pembangunan desa dapat dikontrol dengan baik, setiap kemajuan pembangunan dapat dipantau secara online. Dalam pengelolaannya sistem ini sudah terkoneksi dengan sistem e-village budgeting, semua program pembangunan yang telah disusun dan disahkan melalui APBDes dapat dikontrol pelaksanaannya melalui sistem ini. Dalam pelaksanaanya, semua lokasi kegiatan pembangunan fisik harus dimasukan koordinat lokasinya oleh aparat pemerintah desa. Selanjutnya pihak kecamatan atau pengawas pembangunan desa, ketika melakukan pengawasan di lapangan dapat mengambil foto pelaksanaan program pembangunan mulai dari kondisi o persen ketika kondisi proyek belum dikerjakan hingga kondisi 100 persen ketika proyek sudah selesai dikerjakan. Semua dokumen berupa foto kemajuan proyek dapat diunggah di website sehingga dapat dilihat dan dikontrol oleh masyatakat umum. Semua program fisik akan dipantau dengan menggunakan sistem teknologi informasi berbasis fitur Google Map berbayar.

Gandrung JKN,merupakan program dari BPJS Kesehatan yang bersinergi dengan program smart kampung untuk memberikan kemudahan bagi warga desa yang ingin mendaftaran diri sebagai peserta JKNKIS. Melalui program ini, masyarakat desa cukup datang ke kantor desa tidak perlu ke kantor BPJS di Kota 
Banyuwangi. Warga desa cukup membawa semua persyaratan yang diberikan, maka surat permohonannya bisa langsung diproses oleh petugas di kantor desa. Calon peserta yang sudah terdaftar akan mendapatkan nomor virtual akun sebagai peserta BPJS,sehingga mereka bisa melakukan pembayaran secara langsung di BUMDes atau di bank terdekat. Setelah proses pengurusan kartu peserta BPJS Kesehatan selesai, maka kartu JKN-KIS akan dikirim ke alamat peserta melalui PT. POS Indonesia. Program ini merupakan satusataunya inovasi yang mensinergikan proses pendaftaran JKN-KIS sampai ke tingkat desa secara online. Pengembangan program ini merupakan contoh pengelolaan pemerintahan cerdas di desa.

Unit Gawat Darurat Kemiskinan (UGDK),merupakan sistem berbasis website yang digunakan oleh tim pemburu kemiskinan maupun aparat pemerintah desa untuk mendata penduduk miskin di desa. Melalui sistem inipemerintah desa terlibat untuk melakukan pendataan ulang terhadapat warga mikin di desanya, sehingga dapat diketahui dengan jelas beberapa jumlah keluarga miskin di desa ini dan bagaimana intervensi program yang harus berikan pemerintah untuk mengatasi keluarga yang miskin tersebut. Sebelum ada program smart kampung, data kemiskinan di Dinas Sosial dan data penduduk di Dinas Kependudukan dan Catatan Sipil terpisah masing-masing atau belum tergabung menjadi satu database keluarga miskin yang benar. Akibatnya menyulitkan pemerintah dalam penanganan keluarga miskin di desa. Melalui sistem yang terintegrasi dalam program smart kampung dimana kedua data yang sebelumnya terpisah digabungkan menjadi satu database yang mengandung informasi yang jelas. Aparat pemerintah desa membantu mendata ulang mencocokan data kemiskinan dan data penduduk sehinggadapat diketahui dengan jelas data penduduk miskin di desa berdasarakan, nama, NIK, alamat, pososi rumah (geokoding koordinat rumah dengan GPS), dan jenis kemiskinannya. Dengan data kemiskinan yang jelas dapat memudahkan pemerintah dalam melakukan intervensi program penanganan kemisinan yang sesuai dengan kondisi keluarga miskin tersebut.

Program penanganan kemiskinan yang sebelumnya berjalan sendiri-sendiri di setiap SKPD, melalui sistem UGDK semua program dapat terintegrasi menjadi satu sistem. Untuk penangangan pendidikan bagi keluarga miskin dapat terlayani melalui program bantuan beasiswa banyuwangi cerdas bagi mahasiswa, program garda ampuh dan siswa asuh sebaya bagi pelajar. Untuk program kesehatan bagi keluarga miskin penanganannya melalui program penerima iuan bantuandan surat pernyataan miskin. Untuk pemberian bantuan makan bagi keluarga miskin dapat terlayani melalui program rantang kasih dan program pangan non tunai. Untuk bantuan usaha bagi keluarga miskin dapat terlayani melalui program kangoriko dan jalin mitra. Ada juga program untuk merenovasi rumah layan huni dan pembangunan jamban sehat bagi keluarga miskin. Melalui berbagi program penanganan kemiskinan yang terintegrasi dalam subuah sistem dapat memberikan dampak positif bagi penanganan keluarga miskin di Banyuwngi dimana setiap tahun angka kemiskinan di Banyuwangi turun secara drastis.

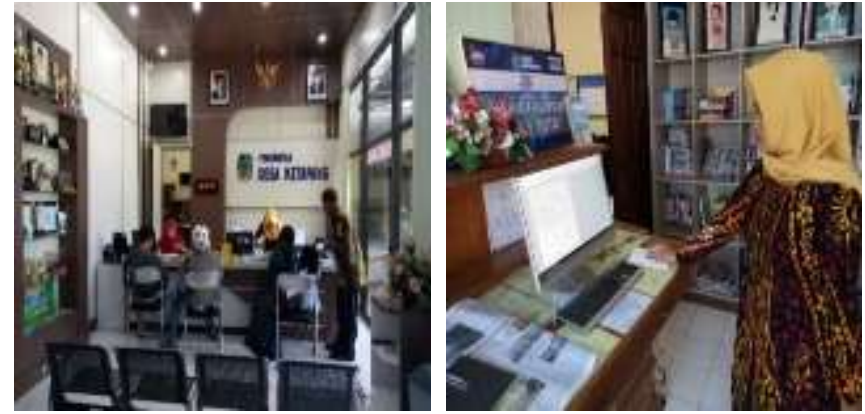

Gambar 4. Palayanan Admininistrasi satu pintu(one stop service)di Desa Ketapang

Sumber. Dokumentasi Penulis, 2018

\section{b. Smart Economy}

Smart Economymerupakan pengelolaan ekonomi cerdas di desa yang bertujuan untuk meningkatkan peluang dan daya saing, produktifitas dan jaringan pasar yang baik di desa. Pengembangan sektor ekonomi cerdas di desa Ketapang melalui pengembangan BUMDes Citra Mandiri. BUMDes merupakan wadah yang digunakan mengerakan ekonomi desauntukmenghasilkan pendapatan asli bagi desa. Pendapatan asli desa merupakan aspek sangat penting bagi desa, karena akan digunakan untuk mendukung berbagai program kegiatan yang direncanakan oleh pemerintah desa. BUMDes juga mempunyai tugas selain sebagai lembaga provit di desa, juga sebagai lembaga sosial untuk mendukung kegiatan pelatihan dan pemberdayaan ekonomi warga desa. Beberapa unit usaha yang dikelola oleh BUMDes Citra Mandiri antara lain;

Pasar Desa,Pemerintah Desa Ketapang melalui BUMDes Citra Mandiri merenovasi pasar desa serta memperbaiki tata kelola manajemen pasar desa menjadi pasar yang lebih modern. Pengelolaan pasar melalui penataan tempat parkir, pengelolaan sampah, pengaturan tempat berjualan, pengelolaan WC dan penarikan retribusi bagi pedagang pasar. Dengan pengelolaan pasar yang lebih baik dapat memberikan pemasukan bagi desa.

Toserba, Untuk usaha ini pemerintah Desa Ketapang bekerja sama dengan distributoruntuk menjual bahan pokok kebutuhan masyarakat. Melalui kerja sama ini ada kesepakatan harga sehingga barang-barang yang dijual di Toserba lebih murah dari toko lainnya. Pemerintah desa juga bekerjasama dengan Bulog untuk menyediakan bahan pokok kebutuhan masyarakat. Selain itu BUMDes juga bekerja sama dengan bank BRI untuk menyedikan fasilitas pembayaran dan penarikan tunai Payment Point Online Bank (PPOB) di Toserba. Toserba juga menjual ATK, Fotokopian, produk-produk kerajinan asli Banyuwangi.

Kantin Desa, BUMDes juga mengembangkan kantin desa sebagai salah satu unit usaha dalam melayani warga desa yang berkunjung ke kantor desa. Kantin ini menyediakan makan dan minum bagi warga desa yang sedang mengurus keperluan di kantor desa atau para pengunjung yang datang beraktifitas di ruang publik di desa seperti menggunakan wifi atau berolahraga. Selain itu kantin juga menyediakan makan untuk seluruh kegiatan yang diselengarakan di Desa Ketapang.

Jasa Pengelola Sampah, BUMDes Cutra Mandiri juga mempunyai unit usaha jasa pengakutan sampah dari rumah makan atau restoran di Desa Ketapang. Selian jasa angkut sampah, BUMDes juga mempunyai unit 
usaha pengelolaan sampah plastik. Program ini nantinya terintegasi dengan program eco literasi yang bertujuan memberikan pembelajaran bagi anak-anak di desa tentang pentingnya menjaga lingkungan di desa agar tetap lestari.

Unit Simpan Pinjam,BUMDes Citra Mandirijuga mengembangkan unit usaha simpan peminjaman bagi warga desa. Unit usaha ini dapat membantu warga desa yang mau mengembangkan usahanya, mereka bisa mengajukan pinjaman tanpa jaminan dengan bunga pinjaman yang rendah sebesar satu persen. Sebelum ada unit usaha ini, warga desa yang melakukan peminjaman ke bank atau koperasi mereka harus membayar tagihan pinjam perhariandengan bunga yang besar sehingga memberatkan warga. Namun setelah adanya unit usaha ini, warga desa untuk mendapatkan pinjaman cukup mudah dan membayar tagihan pinjaman perbulan dengan bunga yang rendah sehingga sangat membantu warga dalam berusaha.

Pengembangan e-commerce,BUMDes Citra Mandiri juga bekerja sama dengan PT. Icon Plus mengembangkan e-commerce BUMDes Citra Mandiri untuk menjual produk-produk idustri rumah tangga, UMKM desa Ketapang secara online. Melalui sistem online, BUMDes sudah pernah mengekspor keripik pisang sebanyak 1000 psc ke negara Timur Leste. Program ini belum berkembang dengan baik, transaksinya juga belum besar karena kita kendala dengan sumber daya manusia dan juga produk yang mau di tawarkan belum terlalu banyak.

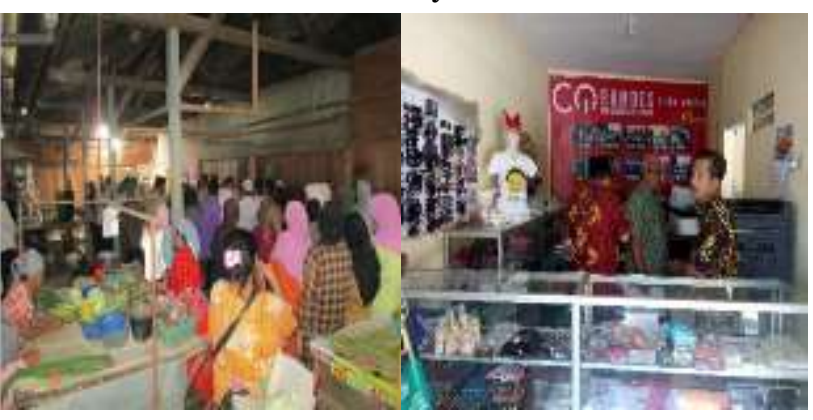

Gambar 5. Unit Usaha BUMDes Citra Mandiri Sumber. Dokumentasi desa Ketapang,2018

\section{c. Smart Living}

Smart Living merupakan pengelolaan hidup yang lebih cerdas bertujuan untuk meningkatkan kualitas hidup warga desa. Di dalam pengembangan program smartkampung, beberapa program kegiatan yang telah dilaksananan terkait dengan pengelolaan hidup cerdas di Desa Ketapang antara lain:

Akses internet gratis, merupakan salah satu aspek penting dalam kegiatan smartkampung. Penyediaan akses internet grastis menjadi sesuatu kebutuhan yang sangat penting bagi desa saat ini untuk mendapatkan informasi yang berguna bagi warga desa dalam mendukung berbagai kegiatan mereka. Berbagai informasi yang dapat diakses warga menggunakan internet gratis seperti membaca informasi atau berita, untuk mendukung pembelajaran secara online bagi pelajar, dan untuk mendukung kegiatan warga dalam mengembangkan usaha mereka serta untuk promosi potensi pariwisata dan penjualan online di desa. Selain itu tersedianya askes internet gratis di balai desa,menjadikan balai desa sebagai pusat informasi dan kegiatan bagi warga desasehinga tercipta ruang komunikasi antar warga di desa yang lebih beragam dan berkualitas dari sebelumnya. Penyediaan akses internet gratis menarik minat warga desa untuk datang melakukan kegiatannya di balai desa sehingga memudahkan pemerintah dalam menyebarkan informasi atau kegiatan pembangunan desa.

Perpustakaan Desa,penyediaan sarana belajar berupa penyediaan buku-buku di perpustakaan desa merupakan aspek penting dalam pengembangan program smart kampung yang bertujuan untuk meningkatkan kualitas hidup warga desa. Perpustakaan desa menyediaan bukubuku untuk pelajar dan juga bacaan umum bagi orang tua yang sedang melakukan kegiatan di balai desa. Perpustakaan desa ini juga terkoneksi dengan program desa literasi yang jangkauan pelayanan dan program yang lebih beragam dan melibatkan berbagai pihak di desa.

Ruang Bermain Untuk Anak, aspek lain dalam pengembangan program smart kampung adalah dengan menyediakan ruang bermain untuk anak agar anak-anak bisa mendapatkan area bermain yang layak dan nyaman di desa. Sarana ini untuk mendukung perkembangan anak, dalam masa pertumbuhannya.

Pertunjukan Seni dan Budaya, balai desa juga sering digunakan untuk kegiatan pelatihan dan pertujukan seni dan budaya asli Banyuwangi. Kegiatan-kegiatan ini untuk mendukung kegiatan pelestarikan budaya yang terancam punah akibat tergerus oleh perkembangan zaman. Selain itu kegiatan ini juga merupakan stategi dalam pengembangan sektor wisata dimana setiap tahun beberapa iven berupa festivalrutin diselengarakan oleh pemerintah desa maupun pemerintah kabupatenuntuk menarik para pengungjung atau wisatawan yang berkungjung ke Banyuwangi. Berbagai kegiatan yang rutin di buat selain dapat memberikan tambahan pemasukan bagi peserta maupun warga desa dapat juga meningkatkan nilai-nilai seni dan budaya sehingga dapat mendukung peningkatan kualitas hidup warga desa.

Kegiatan olah raga,merupakan kegiatan yang rutin diselengarakan di balai desa bertujuan meningkatkan kualitas hidup warga desa. Balai desa juga sering digunakan untuk mendukung kegiatan olah raga seperi senam bagi ibu-ibu, senam jantung bagi warga desa, perlombaan tenis meja dan berbagai perlombaan lain. Berbagai kegiatan yang sering dilakukan untuk mendukung balai desa tidak hanya sebagai pusat pelayanan administrasi tetapi juga menjadi pusat kegiatan olah raga bagi warga desa.

Desa Literasi,merupakan sebuah gerakan sosial yang melibatkan berbagai komponen masyarakat untuk mengembangkan dan membudayakan minat membaca warga desa terutama anak-anak sekolah di desa. Program ini bertujuan untuk mendukung pengembangan Sumber Daya Manusia warga desa yang siap untuk mendukung program-programpembangunan di desa.Beberapa kegiatan yang dilakukan dalam program ini seperti pelatihan bahasa inggris untuk anak usia sekolah maupun para pedagang di kawasan pelabuhan Ketapang. Dalam kegiatan pelatihan bahasa inggris, pemerintah desa bekerja sama dengan Universitas 17 Agustus 1945 setiap tiga bulan melakukan kursus bagi warga desa Ketapang. Pemerintah desa juga mempunyai program school of parenting untuk melatih warga desa yang tidak bisa membaca dan menulis, sehingga dapat memberantas buta aksara di desa. Selain 
itu, pemerintah desa juga melakukan pembinaanbagi warga yang tidak bisa membaca alkuran melalui program pelatihan atau kursus membaca alkuran. Program I-Desa merupakan program inkubasi informasi dan inovasi pengembangan desa. Program ini bertujuan melibatkan warga desa untuk berpartisipasi dalam merencanakan program pembangunan desa dengan menyumbangkan ide, saran, gagas, untuk pengembangan desa.Program Eco literasi, merupakan sebuah gerakan kepedulian terhadap alam di desa. Program ini bertujuan mengajarkan pemuda desa tantang pentingnya menjaga lingkungan serta tidak membuang sampah terutama sampah plastik di sembarangan tempat. Dan berbagai program dan kegiatan lainnya yang terus dikembangkan di desa berdasarkan inovasi dari desa. Dari berbagai kegiatan ini bertujuan untuk meningkatkan kualias hidup warga di desa yang lebih baik.

Rantang Kasih,merupakan program pemberian makana bagi penduduk miskin yang sudah tidak bisa bekerja lagisecera mandiri. Pemerintah desasetiap saat memberikan jatah makan kepada warga yang berhak mendapatkan jatah makan selama 2 kali dalam sehari. Program ini merupakan kepedulian warga dan pemerintah bagi penduduk desa agar mereka bisa menjalani hidup dengan baik di hari tuanya.

Renovasi Rumah dan Jamban, Untuk meningkatkan kualitas hidup warga desa pemerintah desa bersama dengan pemda mempunyai program kerja sama untuk membedah rumah keluarga miskin di desa yang kondisinya sudah tidak layak huni. Selain bedah rumah program renovasi jamban sehat bagi warga miskin juga telah dilakukan didesa. Program ini dalam pelaksanaannya pamerintah hanya membatu warga dalam bentuk bahan bangunan tidak berupa uang sedangkan untuk proses pembangunantenaga kerjanya berasal dari kerja sama warga di desa.

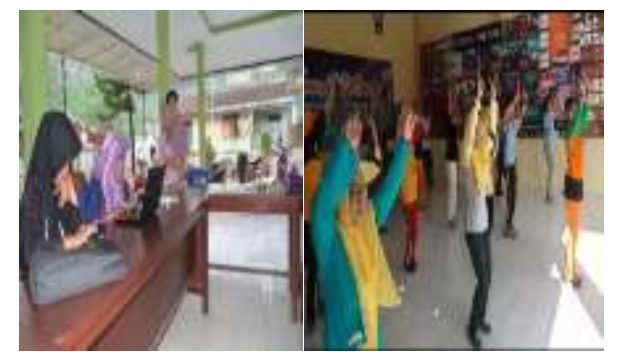

Gambar 6. Aktivitas warga memanfaatkan ruang publik diDesa Ketapang

Sumber. Dokumentasi Desa Ketapang

\section{Tahapan Perkembangan Smart Kampung di Desa Ketapang}

Tahapan pengembangan smart kampung di desa Ketapang terdiri dari4 tahap yaitu tahapan I: persiapan (2011-2015), tahan II: pelaksanaan (ahir tahun 20152016), tahap III: Pengembangan (2017-2018), dan tahap IV: Evaluasi dan Monitoring dilakukan rutin setiap tahun.

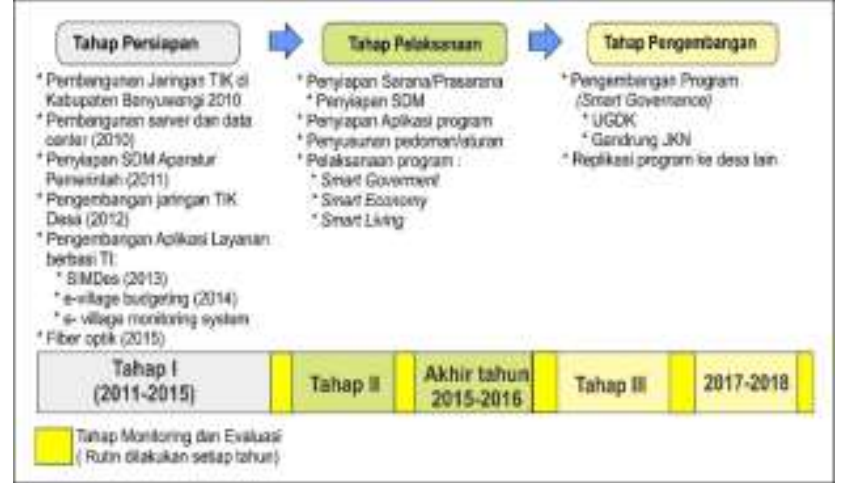

Gambar 7. Tahapan Perkembangan Smart Kampung Sumber. Analisis Penulis,2019

\section{a. Tahap I: Tahap Persiapan (2011-2015)}

Tahapan persiapan merupakan tahapan awalpengembangan program kegiatan sebelum adanya program smart kampung. Dalam tahapan ini beberapa program kegiatan telah kerjakan oleh pemerintah sehingga menjadi pondasi atau landasan dalam pengembangan program smartkampung kelak. Perlu diketahui bahwa sebelum masa kepemimpinan bupati Abullah Azhar Anas ahir tahun 2010, kondisi pemerintahan kabupaten Banyuwangi yang penuh dengan banyak permasalahan sehingga pada saat memimpin bupati fokus memberikan perhatian kepada kegiatan pembenahan layanan pemerintahan mulai dari level kabupaten sampai ke desa. Untuk mendukung kegiatan tersebut beberapa program kegiatan yang dilakukan antara lain dengan pembangunan jaringan infrastruktur teknologi informasi dan komunikasi, pengembangan sumber daya aparat pemerintah, program penguatan komunitas masyarakatdesa serta pengembangan layanan berbasis TI di desa.

Kegiatan pertama yang dipersiapkan pemerintah adalah pembangunan dan pengembangan jaringan infrastruktur TIK sampai ke tingakat pemerintahan desa. Secara umum pembangunan jaringan teknologi informasi dan komunikasi (TIK) di Kabupaten Banyuwangi sudah dimulai sejak tahun 2007 dalam masa kepemimpinan bupati Ibu Renta Ani Lestari. Pada tahap ini, pemerintah bekerja sama dengan pihak operator telekomunikasi pembangunan jaringan TIK sampai ke tingkat kecamatan, dengan membangun tower-tower bersama, membangun radio komunikasi untuk jaringan komunikasi dan internet. Sekitar tahun 2009, semua proses pembangunan jaringan TIK sudah rampung namun terus di upgrade sampai saat ini. Langkah berikutnya di tahun 2010, pemerintah mengembangkan server sistem pusat data (data center) yang dikelola oleh Dinas Komunikasi dan Informatika serta mengembangkan website pemerintah www.banyuwangikab.go.id yang kelak menjadi dasar pengembangan server dan website di masing-masing SKPD maupun desa.

Tahun 2012, pengembangan infrastruktut TIK ke desa secara masif mulai dilakukan oleh bupati Abdullah Azhar Anas. Pengembangan infrastruktur TIK desa sebagai sebuah landasan untuk mendukung gagasan besar bupati yaitu "upaya melipat jarak". Gagasan iniuntuk mengatasi jarak karena faktor jarak yang berjauhan antara desa dan kota selama ini menjadi penghambatbagi warga di desa untuk mendapatkan akses layanan yang baik dari pemerintah. Untuk mendukung gagasan tersebut pemerintah bekerja 
dengan PT. Telkom Indonesia, membangun jaringan internet desa ke seluruh desa di kabupaten Banyuwangi. Dalam program kerja sama ini, pemerintah membangun 1200 titik akses free wifi yang dipasang di berbagai tempat fasilitas publik termasuk di Desa Ketapang.

Pengembangan selanjutnya di tahun 2015, untuk meningkatkan kapasitas jaringan internet desa agar lebih stabil dalam untuk mendukung pengembangan program berbasis TI di desa, maka pemerintah bersama PT. Telkom dan PT. Icon Plus membangun jaringan fiber optik yang menghubungkan semua kantor pemerintah sampai ke desa-desa di seluruh kabupaten Banyuwangi.Ketersediaan jaringan internet dengan kapasitas yang cukup merupakan aspek penting dalam mendukung pelaksanaan program smart kampung.

Kegiatan kedua sekitar tahun 2011 di awal masa kepemimpinan bupati Abdullah Azhar Anas, mulai memberikan perhatian terhadap menyiapkan sumber daya manusia aparatur pemerintah. Pengembangan SDM menjadi perhatian bupati, karenadengan sumber daya aparatur pemerintah yang baik menjadi modal dasar dalam mendukung program perubahan yang gencar digalakan oleh bupati. Pengembangan SDM pada tahap awal lebih lebih pada aparat pemerintah di tingkat kabupaten. Mereka ini bertangungjawab terhadap berbagai inovasi program berbasis TI di kabupaten Banyuwangi serta bertugas melatih dan menyiapkan SDM pengelola di level bawahnya seperti pemerintah kecamatan dan desa.

Untuk meningkatkan kualitas sumber daya manusia, pemerintah melakukan kegiatan seperti mengirim aparat pemerintah untuk melanjutkan pendidikan ke jenjang yang lebih tinggi dengan bekerja sama dengan berbagai Universitas di Indonesia agar mereka dapat melanjutkan pendidikan di sana. Pemerintah juga mengirim aparatur pemerintah mengikutikegiatan pendidikan dan pelatihan di Badan Pengkajian dan Penerapan Teknologi (BBPT) terutama untuk pengembangan TI. Selain itu pemerintah juga melakukan pembenahan dalam rekrutment pegawai pemerintah yang sesuai dengan kapasitas. Program kegiatan ini, bertujuan untuk meningkatkan kompetensi dan kualifikasi serta kemampuan yang baik dari aparatur pemerintah terutama dibidang teknologi informasi. Berbagai program lain yang rutin digalakan pemerintah bertujuan untuk menyiapkan sumber daya aparatur pemerintah yang berkualitas, karena dengan kualitas SDM yang baik akan menjadi pondasi dasar untuk mendukung pengembangan program inovasi di kabupaten termasuk programsmart kampung.

Kegiatan ketiga program peningkatan kualitas masyarakatdesa. Kabupaten Banyuwangi sebelumnya termasuk dalam salah satu kabupaten miskin di Provinsi Jawa Timur, maka pemerintah memberikan perhatian serius terhadap pengentasan masalah tersebut. Bebepa program pengentasan kemiskinan seperti memberikan bantuan beasiswa bagi anak-anak yang putus sekolah dari keluarga miskin, memberikan bantuan biaya kesehetan bagi keluarga miskin dan juga untuk menghapus citra Banyuwangi sebagai kota santet maka program pengembangan pariwisata dalam bentuk festival-festival yang rutin digalakan oleh pemerintah tingkat kabupaten atau desa untuk merubah citra dan mengangkat kepercayaan diri warga kabupaten Banyuwangi. Berbagai kegiatan ini untuk menguatkan modal sosial masyarakat di kabupaten Banyuwangi sehingga mereka siap bekerja sama dan mendukung berbagai program perubahan yang didorong ole bupati Banyuwangi.

Kegiatan ke empat untuk mendukung kemudahan layanan kepada masyarakat, di tahun 2013 pemerintah mengembangkan aplikasi layanan berbasis TI di desa seperti pengembangan SIMDes untuk mendukung pelayanan administrasi penduduk. Dan di tahun 2014 pemerintah mengembangkan aplikasi untuk mengelola dan melaporkan kekuangan desa berbasis online $e$ village budgeting dan e-village monitoring system. Berbagai kegiatan tersebut menjadi dasar dalam pengembangan program smart kampung di ahir tahun 2015 .

\section{b. Tahap II: Tahap Pelaksanaan (2015-2016)}

Diakhir tahun 2015, untuk mengatasi berbagai permasalah pembanguanan di desa terutama permasalahan terkait jarak yang berjauhan antara desa dan kota maka kebijakan yang di ambil bupati Abdullah Azhar Anas adalah dengan mengembangkan program smart kampung. Alasan pengembangan program smart kampung, menurut penjelasanbupati dalam wawancara dengan Antara TV sebagi berikut:

"Kondisi desa di Kabupaten Banyuwangi, dimana letak desa terjauh dari pusat layanan pemerintah di kota Banyuwangi berjarak sekitar $80 \mathrm{~km}$. Hanya untuk mendapatkan pelayanan pemerintah warga desa harus melakukan perjalan ke kota sekitar 3 jam perjalanan dengan kendaraan bermotor sehingga menyulitkan mereka. Saat ini, kampung-kampung memerlukan sistem pelayanan yang smart untuk mengatasi hambatan yang terjadi di desa. Kondisi ini mendorong kami membuat sistem yang bagus, agar rakyat di desa bisa mendapatkan pelayanan yang pasti dan cerdas. Menurut saya, itu sesuatu yang mendesak makanya kita buat sistem yang namanya "SmartKampung". Kita menggunakan TI sebagai kendaraan utama untuk mendekatkan pelayanan pemerintah kepada masyarakat di desa". (Sumber Antara TV; SmartKampung Banyuwangi tanggal 10 Oktober 2017).

Untuk mendukung perlaksanaan program tersebut, maka pemerintahmenyiapkan beberapa kegiatan seperti penyiapan sarana dan prasarana pendukung di balai desa, penyiapan SDM aparat desa, pengembangan aplikasi layanan untuk mendukung pelayanan di desa, penyusunan pedoman/aturan pelaksanaan program, dan peluncuran program kegiatan di desa.

Kegiatan pertama penyiapan sarana dan prasaranadi kantor desa merupakan salah satu indikator utama dalam pelaksanaan program smart kampung. Perubahan mendasar dalam pelaksanaan program smart kampung yaitu dengan pembenahan balai desa yang lebih terbuka dan ramah terhadap warga desa. Sebelum ada programsmart kampung, imagekantor desa adalah gedung yang tertutup bagi warga desa dengan pagar pembatas yang tinggi, dengan fasilitas pendukung yang tidak lengkap, sehingga tidak menjadi pusat kegiatan dan informasi bagi warga desa. Untuk merubah image tersebut, pembenahan dimulai dengan membongkar pagar-pagar pembatas kantor desa yang tinggi sebagai simbol pemisah antara warga dan pemerintah desa. Peyiapakan ruang pelayanan publik yang nyaman dengan penyediaan sarana dan prasarana pendukung 
yang lebih memadai dari sebelumnya. Penyiapan sarana dan prasarana yang lengkap di kantor desa, untuk merubah citra desa yang lebih terbuka dan ramah dalam melayani kepentingan publik dan juga sebagai pusat informasi dan pusat kegiatan ekonomi bagi warga desa.

Tabel.1. Sarana dan Prasaran di Desa Ketapang

\begin{tabular}{|c|c|}
\hline Sarana & Prasarana \\
\hline $\begin{array}{l}\text { Kantor desa \& Ruang } \\
\text { Pertemuan, Mushola }\end{array}$ & Jaringan listrik \\
\hline $\begin{array}{l}\text { Mebeler (meja, } \\
\text { kursi,almari,) }\end{array}$ & Air bersih \\
\hline Sound System & Toilet bersih \\
\hline LCD Proyektor & Tempat sampah \\
\hline CCTV & $\begin{array}{l}\text { Media cetak (koran, } \\
\text { majalah, dll) }\end{array}$ \\
\hline Finger prit & $\begin{array}{l}\text { Penghijauan pohon, } \\
\text { bunga) }\end{array}$ \\
\hline Peralatan komputer & Perpustakaan desa \\
\hline Self services & $\begin{array}{l}\text { Jaringan internet fiber } \\
\text { optik }\end{array}$ \\
\hline Smart TV & $\begin{array}{l}\text { Akses freewifi untuk } \\
\text { publik }\end{array}$ \\
\hline Papan informasi & $\begin{array}{l}\text { Fasilitas untuk orang } \\
\text { berkebutuhan khusus }\end{array}$ \\
\hline $\begin{array}{l}\text { Sarana/prasarana } \\
\text { belajar untuk anak- } \\
\text { anak }\end{array}$ & $\begin{array}{l}\text { Kantor Bumdes, kantin } \\
\text { sembako, ruko }\end{array}$ \\
\hline Pos Keamanan & $\begin{array}{l}\text { Fasilitas kebersihan, motor } \\
\text { sampah, dll. }\end{array}$ \\
\hline
\end{tabular}

Sumber. BPMD, 2018

Kegiatan ke dua penyiapan SDM aparatur desa,Penyiapan SDM aparat desa yang berhubungan dengan pengelolan program berbasis TI sudah dimulai sejak tahun 2013 melalui program SIMDes dan terus di upgrade sampai saat ini. Untuk menyiapakan SDM pelaksana program, pemerintah melalui instanasi teknis setiap tahuan rutin menyelengaran program pelatihan dan pendampingan bagi operator pelaksana program smart kampung. Operator desa yang dilatih untuk mengelola program smart kampung terdiri dari dua orang yaitu yang pertama operator yang bertugas untuk mengelola program layanan administrasi dan kedua operator yang bertugas untuk mengelola program perencanaan dan pengelolaan keuangan desa (e-village budgeting). Selain itu, pemerintah juga rutin melakukan kegiatan pendampingan bagi aparat desayang bertujuan untuk meningkatkam kapasitas aparatur pemerintah desa dalam mengelola pemerintahanya. Untuk meningkatkan kualitas SDM pemerintahan desa, pemerintah juga telah melakukan terobosan dengan memberikan beasiswa bagi aparatur desa untuk melanjutkan pendidikan perguruan tinggi di Banyuwangi.

Kegiatan ke tiga pengembangan aplikasi layanan, untuk mendukung pelaksanaan program smart kampung Diskominfo sebagai pihak yang berwenang mengelola server dan jaringan interenet, mereka mengembangkan aplikasi berbasis website yang dapat digunakan oleh pemerintah desa untuk mendukung pelaksanaan program smartkampung.Adapun aplikasi program yang dikembangkan antara lain:

Tabel 2. Aplikasi dalam program smart kampung

\begin{tabular}{|c|c|c|}
\hline Kegiatan & Website & Fungsi \\
\hline $\begin{array}{l}\text { Surat } \\
\text { menyurat } \\
\text { online }\end{array}$ & $\begin{array}{l}\text { http://portal.Ban } \\
\text { yuwangikab.go.id/ } \\
\text { Http://SIMDes.K } \\
\text { etapang }\end{array}$ & $\begin{array}{l}\text { Sistem ini digunakan } \\
\text { untuk mengurus } \\
\text { berbagai surat } \\
\text { keterangan. }\end{array}$ \\
\hline $\begin{array}{l}\text { SIAK } \\
\text { online }\end{array}$ & $\begin{array}{l}\underline{\text { http://siak.Banyu }} \\
\underline{\text { wangikab.go.id:80 }} \\
\underline{8}\end{array}$ & $\begin{array}{l}\text { Untuk mencari data } \\
\text { penduduk yang sudah } \\
\text { terekam dalam e- } \\
\text { KTP. }\end{array}$ \\
\hline $\begin{array}{l}\text { Procot } \\
\text { online }\end{array}$ & $\begin{array}{l}\text { http://akta.Banyu } \\
\text { wangikab.go.id }\end{array}$ & $\begin{array}{l}\text { Untuk pengurusan } \\
\text { akta kelahiran }\end{array}$ \\
\hline $\begin{array}{l}\text { SPM } \\
\text { online }\end{array}$ & $\begin{array}{l}\text { http://tkpk.Banyu } \\
\underline{\text { wangikab.go.id }}\end{array}$ & $\begin{array}{l}\text { Untuk pengurusan } \\
\text { surat pernyataan } \\
\text { miskin }\end{array}$ \\
\hline $\begin{array}{l}\text { e-Planning } \\
\text { keuangan } \\
\text { desa }\end{array}$ & $\frac{\text { http://evb.Banyu }}{\text { wangikab.go.id/ }}$ & $\begin{array}{l}\text { Untuk perencanaan } \\
\text { dan pengelolaan } \\
\text { keuangan desa }\end{array}$ \\
\hline e-Monev & $\frac{\text { http://ems.Banyu }}{\underline{\text { wangikab.go.id/ }}}$ & $\begin{array}{l}\text { Untuk monitoring } \\
\text { dan evaluasi program } \\
\text { pembangun desa }\end{array}$ \\
\hline $\begin{array}{l}\text { Database } \\
\text { keluarga } \\
\text { miskin }\end{array}$ & $\underline{\text { http://ugdk.Bany }}$ & $\begin{array}{l}\text { Untuk mendata } \\
\text { keluarga miskin dan } \\
\text { untuk } \\
\text { mengintegrasikan } \\
\text { program } \\
\text { penangannya. }\end{array}$ \\
\hline
\end{tabular}

Sumber. Analisis penulis,2019

Kegiatan ke emat yaitu penyusunan pedoman/aturan pelaksana program smart kampung. Smart kampung merupakan program yang baru dikembangkan di Banyuwangi sehingga pemerintah harus menyusun sebuah pedoman atau aturan yang menjadi acuan dalam pelaksanaan program ini di desa. Pemerintah kabupaten Banyuwangi menyusun Peraturan Bupati Nomor 18 Tahun 2016 tentang integrasi program kerja desa/kelurahan melalui program smart kampung. Peraturan ini, menjadi pedoman dalam pengembangan program smartkampung di desa-desa lainnya.

Kegiatan ke lima peluncuran program, setelah penyiapan beberapa kegiatan untuk mendukung terlaksananya program smart kampung, sekitar bulan mey 2016 secara simbolis menteri komunikasi meluncurkan pilot projet smart kampung di 23 desa termasuk di desa Ketapang[12]. Setelah peluncuran program ini, kegiatan pelayanan pubik terutama pelayanan administrasi penduduk bisa diurus di kantor desa. Program ini mendekatkan pelayanan pemerintah kepada warga desa sehingga mereka tidak perlu ke kota Banyuwangi hanya untuk surat-surat administrasi pemerintah yang selama terjadi. Melalui program ini, kini semua urusan yang berhubungan dengan masalah adiministrasi penduduk, masalah pendidikan, masalah kesehatan semua dapat terurus secara langsung di kantor desa.

\section{c. Tahap III: Pengembangan (2017-2018)}

Setelah program smart kampung diluncurkan oleh menteri komunikasi dan informatika tahun 2016,pemerintah melihat bahwa program ini tidak hanya digunakan untuk mengurus surat-surat administrasi penduduk tetapi program ini dapat dikembangkan lebih luas untuk mengintegrasikan berbagai program kegiatan lainnya untuk mengatasi berbagi masalah di Kabupaten Banyuwangi. Dalam pengembangannya pemerintah memanfaatkan sistem smart kampung mengatasi masalah kemiskinan. Melaluismart kampung, tim penangulangan kemiskinan mendata ulang jumlah keluargamiskin secara benar. 
Selama inidata-data kemiskinantersebar di berbagi SKPD, belum menjadi satu data yang falid sehingga menyulitkan pemerintah dalam mengembangkan program pengentasan kemiskinan secara efektif. Namun setelah pengembangan program smart kampung integrasi data dan program pananganan kemiskinan menjadi lebih baik dalam sistem nit gawat darurat kemiskinan.

Tahun 2018 pemerintah bekerja sama dengan BPJS mengembangkan program Gandrung JKN yang bersinergi dengan program smart kampung. Program ini memberikan kemudahan kepada warga desa untuk mendaftarkan diri sebagai peserta JKN-KIS. Dengan sistem ini semua proses mulai dari pendaftaran, pembayaran sampai dengan penerimaan kartu semuanya dilakukan di kantor desa.

Setelah peluncuran program smart kampug di 23 desa, pemerintah mendorong pengembangan program tersebut ke untuk dikembangkan ke desa lain secara bertahap. Sampai tahun 2018 sebanyak 189 desa di kabupaten Banyuwangitelah menerapkan mengembangkan konsep smart kampung sebagai sebuah kebijakan utma dalam mendukung pembangunan di desa.

\section{d. Tahap IV: Evaluasi dan Monitoring}

Kegiatan monitoring dan evaluasi program smartkampung merupakan kegiatan rutin setiap tahun dilakukan oleh pemerintah kabupaten Banyuwangi. Kegiatan monitoring dan evalusi program smart kampung dilakukan dalam bentuk kegiatan perlombaan smart kampung. Dimana dalam pelaksanaannya, pemerintah menilai pelaksanaan program pembangunan desa sesuai dengan kriteria-kriteria desa cerdas yang telah ditetapkan. Kegiatan perlombaan desa cerdas, merupakan strategi pemerintah agar masyarakat dan pemerintah desa lebih inovatif mengembangkan program kegiatan pembangunan desa yang terintegrasi dengan program smart kampung.

\section{Pihak-Pihak Yang Terlibat}

Smart Kampung merupakan sebuah inovasi program yang melibatkan banyak pihak yang terlibat dalam proses pengembangan maupun dalam pelaksanaannya. Pihak-pihak yang terlibat dalam pengembangan program smart kampung sebagai berikut:

\section{a. Pemerintah}

Dalam program pengembangan smart kampung, pemerintah merupakan aktor utama sebagai motor pengerak program.Smartkampung merupakan sebuah program inovasi yang berkembang cukup dinamis sehingga diperlukan terobosan-terobosan yang luar bisa dalam pengembangannya. Untuk mendukung program ini faktor kepemimpinan merupakan kunci utama dalam pelaksanaan program. Pemimpin berkarakter bureaupreneurshipmerupakan pemimpin yang dibutuhkan dalam memimpin penyelengaraan pemerintahan sehingga program ini dapat berjalan di suatu daerah. Bureaupreneurship merupakan kepemimpinan yang mempuyai kemauan politik kuat untuk melakukan perubahan, mengetahui pelaksanaan birokrasi dengan baik dan mempunyai jiwa dan semangat enterpreneuership (kewirausahaan). Dengan jiwa dan semangat enterpreneurship, dimana melihat berbagai persoalan sebagai suatu peluang untuk melakukan perubahan. Pemimpin berkarakter ini, merupakan pemimpin yang dapat bekerja secara profesional, dapat bekerja sama dengan berbagai pihak dan penuh dengan berbagai inovasi program.

Pemerintah kabupaten Banyuwangi sebelum masa kepempinan bupati Abdullah Azhar Anas banyak permasalahan yang terjadi dalam penyelengaraan pemerintah. Setelah pemerintahan di pimpin oleh bupati Abdullah Azhar Anas dengan karakter kepemimpinan bureaupreneurship mulai mendorong berbagai program untuk memperbaiki kualitas layanan dalam penyelengaraan pemerintah di Kabupaten Banyuwangi. Pemerintahmulai dengan program pengembangan infrastruktur dasar dan infrastruktur TIK di desa, pembenahan internal pemerintah dengan pengembangan sumber daya manusia, dan pengembangan layanan berbasis pada penggunaan teknologi informasi. Pemerintah mendorong pengembangan dan integrasi berbagai program pemerintah dari setiap SKPD untuk dilaksanakan di desa. Dengan berbagi program kegiatan yang telah dikerjakan pemerintah menjadi dasar dalam pengembangan program smart kampung di Desa Ketapang maupun di seluruh desa di Kabupaten Banyuwangi.

\section{b. Swasta}

Pihak swasta juga memegang peran yang cukup penting dalam pengembangan program smart kampung. Pihak swasta berperan dalam pengadaan infrastruktur TIK ke desa. Pihak swasta terutama PT. Telkom dan PT. Icon Plus bertanggung jawab dalam pembanguan jaringan internet ke desa dan juga bertangung jawab dalam mengembangkan aplikasi pelayanan berbasis TI. Selain teknologi salah satu faktor penting dalam mendukung pengembangan program smart kampung adalah ketersediaan energi listrik dengan daya yang cukup. PT. Perusahaan Listrik Negara (PT. PLN) merupakan pihak yang bertangung jawab untuk menyediakan energi litrik ke seluruh kantor-kantor desa. Selain itu PT. Pos Indonesia terlibat dalam pelaksanaan program smart kampung untuk pengiriman dokumendokumen surat administrasi yang telah selesai diurus ke rumah masyarakat atau ke kantor desa.

\section{c. Masyarakat}

Masyarakat mempunyai peranan yang cukup penting dalam pelaksanaan program smart kampung. Tanpa dukungan dari masyarakat maka program ini tidak dapat dilaksanakan di lapangan. Peran masyarakat dalam mendukung pelaksanaan program smart kampung dapat dilihat dari berbagai inovasi program yang coba mereka buat dan terlibat dalam pelaksanaannya. Program pengembangan ekonomi desa, program pengentasan kemiskinan, program pengembangan sumber daya manusia dan program pengembangan seni dan budaya banyak melibatkan peran masyarak. Sebagai contoh Peran masyarakat dalam pengembangan program desa literasi, dimana dalam pelaksanaan program ini masyarakat terlibat 
sebagai relawan untuk mendukung pelaksanaan program di desa.

\section{d. Media}

Media mempunyai peran yang cukup besar dalam pelaksanaan program ini. Pemberitaan media baik melalui media cetak maupun online memberikan energi positive bagi pengembangan program ini. Pemberitaan yang dilakukan oleh media, terutama melalui media sosial memberikan pengaruh positive dalam pengembangan program ini.

\section{Struktur Pengembangan}

Struktur pengembangan program smart kampung terdiri dari program pondasi dan program pilar yang telah dikembangkan oleh pemerintah. Program pondasi merupakan program dasar yang telah dilakukan sebelum pengembangan program smart kampung di Desa Ketapang. Sedangkan program pilar merupakan program yang dilakukan setelah program pondasi dilakukan. Di dalam pengembangan program smart kampung yang menjadi program pilar adalah program kegiatan yang termasuk dalam dimensi pengembangan program smart kampung

\section{a. Pondasi}

Pengembangan program smart kampung di Desa Ketapang, ada beberapa program yang telah dilakukan oleh pemerintah daerah sehingga menjadi dasar dalam pengembangan program smart kampung kelak. Program-program yang menjadi pondasi dalam pengembangan program smart kampung adalah program pengembangan jaringan TIK dan aplikasi layanan ke desa, program pengembangan sumber daya aparatur pemerintah, dan program pengembangan komunitas masyarakat desa. Ketiga program ini menjadi pondasi dalam mendukung pengembangan program smart kampung di Banyuwangi.

\section{b. Pilar}

Program-program pilar dalam pelaksanaan program smart kampung adalah program-program yang menjadi dimensi dalam pelaksanaan program smart kampung. Di dalam pelaksanaan program smart kampung yang menjadi program pilar adalah program pelayanan adminitrasi publik(smart governance), program pengembangan ekonomi(smart economy), program penanganan kemiskinan, program pendidikan, seni dan budaya, dan program kesehatan(smart living). pengembangan program pilar ini berdasarkan prioritas pemerintah untuk mengatasi permasalahan yang terjadi di desa.

Program pelayanan administrasi merupakan pilar pertama yang menjadi fokus pengembangan program smart kampung. Program ini digagas untuk mendekatkan pelayanan kepada masyarakat di desa karena mereka selama ini terhambat untuk mendapatkan pelayanan pemerintah akibat jarak yang berjauhan antara desa dan kota sebagai pusat pelayanan pemerintah. Program berikutnya yaitu pengembangan ekonomi desa melalui pengembangan BUMDes sebagai motor pengerak ekonomi desa. Desa dengan berbagai potensi yang dimiliki memerlukan manajemen yang baik untuk mengelola dan mengembangkan potensi tersebut sehingga memberikan pendatan kepada pemerintah desa. Dengan pendapatan desa yang cukup akan mendukung pengembangan berbagai program pemerintah di tingkat desa.

Program pilar berikutnya yaitu program pengentasan kemiskinan. Program ini merupakan prioritas utama penerintah kabupaten Banyuwangi untuk menurunkan angka kemiskinan yang tinggi di kabupaten Banyuwangi. Program pengembangan sumber daya manusia merupakan program pilar berikutnya yang gencar di dorong oleh pemerintah untuk mendorong pengembangan sumber daya manusia di kabupaten Banyuwangi dengan memberikan beasiswa bagi para pelajar dan mahasiswa serta pengembangan berbagai kegiatan memanfaatkan ruang publik di desa seperti perpustakaan desa, penggunaan internet dan lain sebagainya. Program kesehatan merupakan merupakan program pilar berikutnya dimana pemerintah memberikan pengobatan gratis bagi keluarga miskin yang menderita sakit. Program pendidikan, seni dan budaya merupakan program pilar yang dilaksanakan di desa. Pengembangan rumah baca atau perpustakaan, pelatihan dan pentasan seni dan budaya yang rutin di selegarakan di desa memberikan pengaruh dalam pengembangan program smart kampung di desa.

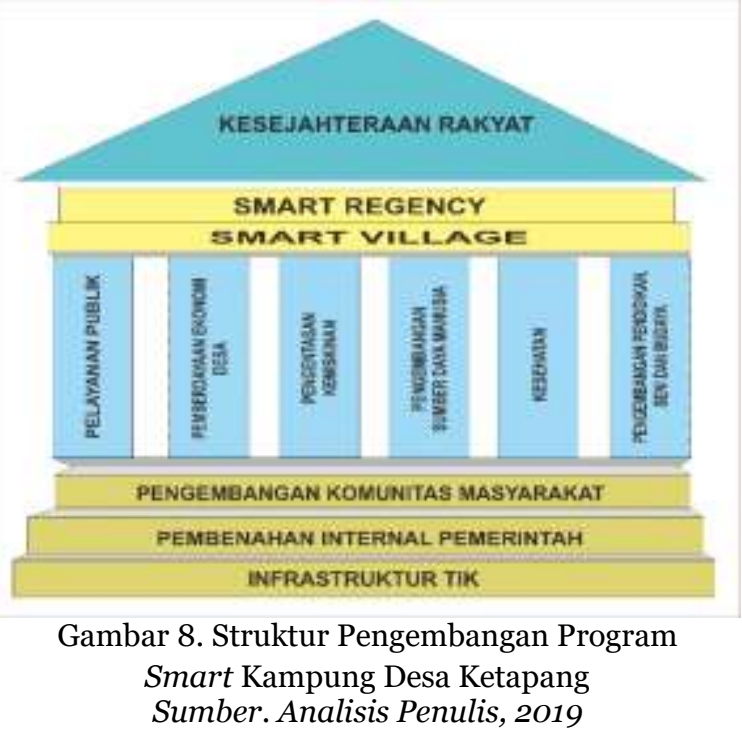

\section{Faktor-faktor Yang Berpengaruh}

Dalam pembahasan tahapan perkembangan smart kampung ditemukan faktor-faktor yang berpengaruh terhadap tahap pengembangan smart kampung di Desa Ketapang, yakni:

\section{a. Kepemimpinan}

Pemerintah sebagai aktor utama yang mengerakan program smartkampung, tidak terlepas dari dukungan kepemimpinan. Kepemimpinan yang mempunyai kemauan politik (political will) yang kuat menjadi faktor kunci yang menentukan keberhasilan pelaksanaan program smart kampung. 
Kepemimpinan yang dibutuhkan mengerakan program ini harus berkarakter bureaupreneurship. Bureaupreneurshipmerupakan tipe kepemimpinan yang mengerti manajemen birokrasi pemerintahan secara baik dan sekaligus memiliki jika kewirausahaan (enterpreneurship)agar mampu mendrive program kegiatan pemeritah di era digital saat ini. Bupati Banyuwangi Abdullah Azhar Anas, merupakan salah satu pemimpin yang berkakter bureaupreneurship. Karena mampu mendorong berbagai inovasi program pembangunan di kabupaten Banyuangi termasuk program smart kampung sehingga program tersebut dapat berkembang dengan baik dalam beberapa tahun belakangan ini.

Selain kepemimpinan bupati, kepemimpinan Kepala Desa Ketapang juga merupakan salah satu faktor penting dalam mendukung pengembangan program smartkampung di desa ini. Peranan Kepala Desa cukup besar dengan mengembangkan berbagai inovasi program smart kampung dan mendukung partisipasi warga dalam pelaksanaan program desa. Pengembangan BUMDes dengan berbagai unit usaha yang terus berkembang, dan pengembangan desa literasi yang cukup berkembang dengan baik karena pengaruh kepemimpinan kepala Desa Ketapang. Selain itu, kepala desa juga berani melakukan terobosan dengan bekerja sama dengan institusi perguruan tinggi untuk mendampingi desa dalam pengembangan ekonomi masyarakat desa. Mengembangan program pendidikan literasi desa, dan merekrut beberapa tenaga kerja untuk bekerja di desa yang mempunyai besik ilmu yang cukup baik dalam bidang teknologi informasi sehingga mendukung pelaksanaan program smart kampung di desa ini dapat berkembang dengan baik. Kepimpinan kepala desa Ketapang juga berkarakter bureaupreneurship, karena kepemimpinan kepala desa yang mampu melaksanakan program pelayanan pemerintah dengan baik dan juga ikut mendorong berbagai program inovasi desa sehingga berhasil dalam penerapannya.

\section{b. Teknologi}

Salah satu faktor yang mendukung pengembangan program smart kampung di Desa Ketapang adalah dukungan teknologi seperti tersedianya jaringan internet di desa. Pengembangan internet gratis ke desa menjadi faktor penting mendukung pelayanan kepada masyarakat berbasis TI di Desa Ketapang. Selanjutnya pengembangan jaringan internet dengan pemasangan jaringan fiber optik merupakan faktor pendukung utama dalam mendukung pelaksanaan program smart kampung. Selain jaringan internet, penggunaan teknologi sederhana bukan teknologi tinggi yang dapat digunakan oleh masyarakat desa dengan mudah merupakan salah satu faktor pendukung dalam keberhasilan program smart kampung. Penggunaan smartphone, penggunaan komputer,CCTV, wifi, pengembangan layanan self services, penggunaan fingerprint, pemasangan smart TV, serta pengembangan aplikasi layanan yang dapat dioperasikan dengan mudah merupakan kunci sukses pengembangan program smart kampung. Selain penggunaan teknologi, pelatihan bagi operator yang diterus digalakan oleh pemerintah, agar mereka dapat menggunakan aplikasi yang terhubung dengan program smart kampung merupakan faktor pendukung terlaksananya program smart kampung.

\section{c. Partisipasi Warga}

Faktor partisipasi warga merupakan salah satu faktor pendukung dalam pelaksaan program smart kampung. Desa Ketapang merupakan desa maju di Kabupaten Banyuwangi. Karena termasuk dalam desa maju, sehingga mereka mempunyai potensi sumber daya yang cukup baik untuk mendukung pelaksanaan program ini. Partisipasi warga dapat ditunjukan dengan berbagai program inovasi yang dibauat di Desa Ketapang dapat berkembang dengan baik. Program desa literasi, dimana pemuda desa ikut terlibat secara aktive dalam pelaksanaan program ini. Selain itu keterlibatan warga desa melalui program pengembangan ekonomi desa seperti pengembangan unit usaha BUMDes. Warga desa juga terlibat secara aktif dalam program-program kegiatan yang dibuat oleh pemerintah desa seperti pelatihan bahasa inggris untuk pedagang di Desa Ketapang, kegiatan pelatiahan dan pengembangan ekonomi bagi warga desa dan berbagai kegiatan lain seperti kegiatan olahraga, seni dan budaya yang rutin di gelar di kantor desa.

\section{d. Alokasi Anggaran}

Alokasi anggaran untuk desa yang bersumber dari APBN dan APBD dan juga dari pendapatan asli desa merupakan faktor mendukung terlaksananya program smart kampung.Dukungan anggran desa yang cukup besar kepada pemerintah desa, memberikan keleluasaan bagi pemerintah desa untuk merencanakan program pembangunan desa secara mandiri. Inovasi program smart kampung dapat terlaksana karena adanya dukungan anggaran desa.Dana tersebut sebagian digunakan untuk mendukung pelaksanaan program smart kampung seperti untuk menyiapkan sarana dan prasarana untuk mendukung pelaksanaan program smart kampung. Pembenahan kantor desa, perbaikan ruang pelayanan, pemasangan jaringan fiber optik, pembayaran tagihan internet setiap bulan, pemasangan CCTV dan lain sebagainya. Selain itu dukungan dana desa juga untuk mendukung program pilar smart kampung seperti: penanganan kemiskinan, program pengembangan sumber daya manusia, dan program pengembangan ekonomi desa dan berbagai program lainya.

\section{SIMPULAN DAN SARAN}

Berdasarkan hasil pembahasan yang telah dijelaskan diatas maka dapat disimpulkan bahwa tahapan pengembangan smart kampung desa Ketapang terdiri dari tahapan persiapan (2011-2015), tahapan 
pelaksanaan (ahir tahun 2015-2016), tahapan pengembangan (2017-2018), dan tahapan monitoring dan evaluasi (dalam setiap tahun). Program kegiatan yang dilakukan dalam tahap persiapan terdiri dari pembangunan infrastruktur TIK dan pengembangan aplikasi layanan, penyiapan sumber daya aparatur pemerintah dan pengembangan komunitas masyarakat. Program kegiatan yang dilakukan dalam tahapan pelaksanaan antara lain penyiapan sarana dan prasarana di desa, penyiapan SMD aparatur desa, pengembangan aplikasi pelayanan di desa, penyiapan pedoman atau aturan pelaksanaan, dan peluncuran program. Program kegiatan dalam tahap pengembangan antara lain pengembangan program layanana dan replikasi program ke desa lain. Sedangkan tahap monitoring dan evaluasi merupakan kegiatan rutin yang dilakukan setiap tahun dalam bentuk perlombaan smart kampung.

Dari pembahasan tahapan perkembangan smart kampung ditermukan lima faktor yang berpengaruh dalam pengembangan program smart kampung di desa ketapang antara lain faktor kepemimpinan, faktor teknologi, faktor dukungan warga, dan faktor alokasi anggaran desa. Faktor yang dominan dalam pengembangan program smart kampung adalah faktor kepemimpinan yang berkarakter bureaupreneurship.

Perkembangan konsep smart village atau smart kampung, merupakan konsep yang baru berkembang sehingga peluang penelitian tentang konsep ini masih perlu dilakukan agar pemahaman tentang konsep ini menjadi lebih jelas. Dalam penelitian ini, peneliti membahas secara umum tahapan perkembangan smart kampung di desaKetapang yang tentunya masih banyak kekurangan dalam penelitian ini. Untuk itu peneliti menyarankan perlu dilakukan penelitian selanjutnya tentang terhadap tingkat perkembangan program smart kampug di setiap desa dan juga pengaruh program smart kampung terhadap perkembangan masyarakat di desa. Selain itu penelitian lain yang perlu dilakukan lebih mendalam pada dimensi pengembangan smart kampung seperti program penanganan kemiskinan, program pengembangan sumber daya manusia dan lain sebagainnya.

\section{UCAPAN TERIMA KASIH}

Penulis mengucapkan banyak terima kasih kepada Prof. Ir. Achmad Djunaedi, MUP.,Ph.D dan Dr. Yori Herwangi, ST, MURP selaku dosen pembimbing yang senantiasa membantu dan membimbing penulis sehingga dapat menyelesaikan penelitian dan penulisan peper ini. Dan juga ucapan terima kasih juga dihaturkan kepada pemerintah Desa Ketapang dan SKPD terknis yang telah membantu dalam proses penelitian di lapangan.

\section{DAFTAR RUJUKAN}

[1] A. Djunaedi et al., Membangun Kota dan Kabupaten Cerdas: Sebuah Paduan Bagi Pemerintah Daerah, 1st ed. Yogjakarta: Gajah Mada University Press, 2018.

[2] R. P. Damiri, Smart City Implementation; Creating Economic and Public Value in Innovative Urban Systems. Genoa; Italia, 2017.

[3] M. Deakin and S. Allwinkle, "Urban Regeneration and Sustainable Communities: The Role of Networks, Innovation, and Creativity in Building Successful Partnerships," J. Urban Technol., vol. 14, no. 1, pp. 7791, 2007.

[4] T. Nam and T. A. Pardo, "Conceptualizing smart city with dimensions of technology, people, and institutions," Proc. 12th Annu. Int. Digit. Gov. Res. Conf. Digit. Gov. Innov. Challenging Times - dg.o '11, p 282, 2011.

[5] R. Giffinger, Christian Fertner, Hans Kramar, Robert Kalasek, N. Pichler-Milanović, and Evert Meijers, "Smart cities Ranking of European medium-sized cities," October, vol. 16, no. October, pp. 13-18, 2007.

[6] N. Viswanadham and S. Vedula, "Design of Smart Villages,” Cent. Glob. Logist. Manuf. Strateg., pp. 1-16, 2010.

[7] S. Chatterjee and A. K. Kar, "Concept of Smart Village in India: A Proposed Ecosystem and Framework Sheshadri," in Advances in Smart Cities; Smart People, Governance, and solution, A. K. Kar, M. P. Gupta, P. V. Ilavarasan, and Y. K. Dwivedi, Eds. London: Taylor \& Francis Group Press, 2011, p. 83.

[8] Bupati Banyuwangi, Integrasi Program Kerja Berbasis Desa/Kelurahan Melalui Smart Kampung. Indonesia: Pemerintah Kabupeten Banyuwangi, 2016.

[9] M. Astro, "No TitleAzwar Anas Raih Penghargaan TOP IT dan Telco 2017," Antara Jatim, Jawa Timur, 2017.

[10] S. Arifianto, Implementasi Metode Penelitain Studi Kasus, 1st ed. Yogjakarta: Aswaja Pressindo, 2016.

[11] K. R. Yin, Studi Kasus (Desain dan Metode). Jakarta: Rajawali Press, 2009.

[12] M. Andriansyah, "Menkominfo akan resmikan 41 Desa Smart Kampung di Banyuwangi," Merdeka.COm Banyuwangi, Banyuwangi, 2016. 